\title{
Ginkgolide B Ameliorates Myocardial Ischemia Reperfusion Injury in Rats via Inhibiting Endoplasmic Reticulum Stress [Retraction]
}

Guo C, Zhang J, Zhang P, et al. Drug Des Devel Ther. 2019;13:767-774.

The Editor-in-Chief and Publisher of Drug Design, Development and Therapy wish to retract the published paper.

The journal was notified of potential image duplication between Figure 1E - Sham and Figure 1E - Sham+GB The authors were unable to provide a satisfactory explanation for this alleged duplication. The authors were also unable to provide satisfactory raw data for the western blots shown in this article. The editor determined the findings of the study were no longer valid and requested for the article to be retracted.

The authors wish to apologise for this error.

Our decision-making was informed by our policy on publishing ethics and integrity and the COPE guidelines on retraction.

The retracted article will remain online to maintain the scholarly record, but it will be digitally watermarked on each page as "Retracted".
Drug Design, Development and Therapy

\section{Publish your work in this journal}

Drug Design, Development and Therapy is an international, peerreviewed open-access journal that spans the spectrum of drug design and development through to clinical applications. Clinical outcomes, patient safety, and programs for the development and effective, safe, and sustained use of medicines are a feature of the journal, which has also

\section{Dovepress}

been accepted for indexing on PubMed Central. The manuscript management system is completely online and includes a very quick and fair peer-review system, which is all easy to use. Visit http://www. dovepress.com/testimonials.php to read real quotes from published authors. 